\title{
Framing the difficulties resulting from implementing a Participatory Management Model in a public hospital ${ }^{1}$
}

\author{
Andrea Bernardes ${ }^{2}$ \\ Greta Cummings ${ }^{3}$ \\ Yolanda Dora Martinez Évora ${ }^{4}$ \\ Carmen Silvia Gabriel${ }^{2}$
}

Objective: This study aims to address difficulties reported by the nursing team during the process of changing the management model in a public hospital in Brazil. Methods: This qualitative study used thematic content analysis as proposed by Bardin, and data were analyzed using the theoretical framework of Bolman and Deal. Results: The vertical implementation of Participatory Management contradicted its underlying philosophy and thereby negatively influenced employee acceptance of the change. The decentralized structure of the Participatory Management Model was implemented but shared decision-making was only partially utilized. Despite facilitation of the communication process within the unit, more significant difficulties arose from lack of communication inter-unit. Values and principals need to be shared by teams, however, that will happens only if managers restructure accountabilities changing job descriptions of all team members. Conclusion: Innovative management models that depart from the premise of decentralized decision-making and increased communication encourage accountability, increased motivation and satisfaction, and contribute to improving the quality of care. The contribution of the study is that it describes the complexity of implementing an innovative management model, examines dissent and intentionally acknowledges the difficulties faced by employees in the organization.

Descriptors: Nursing, Team; Organization and Administration; Communication; Health Management.

\footnotetext{
${ }^{1}$ Supported by Fundação de Amparo à Pesquisa do Estado de São Paulo (FAPESP), process \# 2008/03775-5.

2 PhD, Professor, Escola de Enfermagem de Ribeirão Preto, Universidade de São Paulo, WHO Collaborating Centre for Nursing Research Development, Brazil.

${ }^{3} \mathrm{PhD}$, Professor, Faculty of Nursing, University of Alberta, Canada.

${ }^{4}$ PhD, Full Professor, Escola de Enfermagem de Ribeirão Preto, Universidade de São Paulo, WHO Collaborating Centre for Nursing Research Development, Brazil.
} 


\title{
Contextualização das dificuldades resultantes da implementação do Modelo de Gestão Participativa em um hospital público
}

Objetivo: O estudo objetiva abordar as dificuldades relatadas pela equipe de enfermagem durante o processo de mudança do modelo de gestão em um hospital público no Brasil. Método: Este estudo qualitativo utilizou a análise temática de conteúdo proposta por Bardin, sendo os dados analisados usando o referencial teórico de Bolman e Deal. Resultados: A implementação vertical da Gestão Participativa contradiz sua filosofia, influenciando negativamente a aceitação das mudanças por parte dos trabalhadores. A estrutura descentralizada foi implementada, porém a tomada de decisão compartilhada foi apenas parcialmente utilizada. Apesar de haver facilitação da comunicação intraunidade, as dificuldades mais significativas surgiram da falta de comunicação interunidades.Valores e princípios precisam ser compartilhados por equipes, contudo, isso somente ocorrerá se os gestores reestruturarem responsabilidades descrevendo os papéis de todos os membros da equipe. Conclusão: Modelos de gestão inovadores que tenham como premissa a descentralização da tomada de decisão e intensificação da comunicação incentivam a motivação, a responsabilização, o aumento da satisfação do pessoal, além de contribuir para melhorar a qualidade do atendimento. A contribuição do estudo centra-se na descrição da complexidade da implementação de um modelo de gestão inovador, na análise do dissenso e, intencionalmente, no reconhecimento das dificuldades enfrentadas pelos funcionários da organização.

Descritores: Equipe de Enfermagem; Organização e Administração; Comunicação; Gestão em Saúde.

\section{Enmarcando las dificultades de la aplicación del Modelo de Gestión Participativa en un hospital público}

\begin{abstract}
Objetivo: El estudio tiene como objetivo tratar de las dificultades del equipo de enfermería durante el cambio del modelo de gestión en un hospital público en Brasil. Método: Este estudio cualitativo utilizó el análisis de contenido temático propuesto por Bardin; los datos fueron analizados utilizando el marco teórico de Bolman y Deal. Resultados: La aplicación vertical de la Gestión Participativa, en contradicción con su filosofía, incide negativamente en la aceptación del cambio por los empleados. La estructura descentralizada se llevó a cabo, pero la toma de decisiones compartida se utilizó sólo en parte. Aunque existe facilitación de la comunicación dentro de la unidad, dificultades surgieron de la falta de comunicación inter-unidades. Valores y principios deben ser compartidos por los equipos; esto sólo ocurre si los gerentes reestructurar las responsabilidades y describir las funciones de todos. Conclusión: Modelos innovadores de gestión que tienen como premisa la descentralización de las decisiones y una mayor comunicación fomentan la motivación, la responsabilidad, aumento de la satisfacción, y mejoran la calidad de la atención. La contribución de este estudio se centra en la complejidad de la implementación de una gestión innovadora, el análisis de disenso e intencionadamente
\end{abstract} en el reconocimiento de dificultades que enfrentan los empleados de la organización.

Descriptores: Grupo de Enfermería; Organización y Administración; Comunicación; Gestión en Salud.

\section{Introduction}

The historical classical management roots of contemporary accounting are still embedded in theory and practice, even in hospitals(1). In Brazil, most hospitals still have a management system based on a functional model that emphasizes formal and vertical structures. However, such traditional models no longer address the expectations of managers, workers and especially patients, since professional nurses working 
in this context occasionally distance themselves from the care provided to patients. This can work against the nurses' role as professional practitioners who interact directly with clients to affect better health outcomes for patients ${ }^{(2)}$. Thereby, the ability of nurses to affect better health outcomes is also influenced by the management model adopted by an institution.

The world in which public managers function is rapidly changing, indicating a shift towards more decentralization at organizational levels, while promoting management flexibility and autonomy ${ }^{(3)}$. Participatory Management Models refer to the decentralization of organizational decision-making structures into autonomous units, which reflect, the organizational whole ${ }^{(4)}$. These models are based on multidisciplinary teams, fewer layers of hierarchical roles, shared responsibility and balanced power dynamics, developed in the decision-making processes.

Processes of democratization are based on principles of co-management (spaces of struggle / negotiation between different actors) and participatory management, where all workers contribute to the decision-making that affects their work or service. All workers would meet periodically to rethink their work environment, and suggest directions for the organization. Workers' assemblies or councils in the workplace, exercising a form of shared leadership(5), is one example of democratic administration expected today.

Similar to the concept of the Participatory Management Model, shared governance and magnet hospitals bring benefits to patients, nurses and health care institutions. Nurses who are visionary leaders and are ahead of care are able to make decisions, to achieve collective participation in the production of quality care to patients, and allow a more participatory management ${ }^{(6-7)}$.

Anyway, the goal of organizational change is to implement any transformation using knowledge and ideas that work in practice. Based on this, in this study, Bolman and Deal's( ${ }^{(8)}$ conceptual framework was used, who sorted insights from both research and practice about how organizations function into four major frames - Structural, Human Resource, Political, and Symbolic. The central concepts of the Structural frame are rules, roles, goals, policies, technology, and environment. The assumptions of this frame reflect a belief in rationality, which implies that a suitable array of formal roles and responsibilities will minimize people's distraction and maximize their performance on the job. The Human Resource frame deals with needs, skills, and relationships between employees and the organization. Another premise in this frame is that organizations exist to serve people's needs and that people and organizations need each other. The Political frame involves the use of power, conflict, competition and organizational politics, and their impact on organizational effectiveness. The Symbolic frame deals with culture, meaning, metaphor, ritual, ceremony, stories and heroes. The assumption in this frame is that meaning is more important than actual events.

The research intends to answer what are the main difficulties faced by the nursing team in the implementation of an innovative and participatory management model. Although the need to change the management model from a centralized to a participatory and decentralized model is acknowledged in Brazil, overcoming barriers to implementation is not easy(9-10), particularly when the organization has invested in top-down communication, as well as the centralization of power and decision-making. Thus, this study aims to address difficulties reported by nurses during the process of changing the management model in a public hospital in Brazil.

\section{Methods}

This is a historical-organizational case study, focused on work-life outcomes of implementing a new management model in a healthcare institution. Thus, the researcher must have knowledge about the organization under examination ${ }^{(11)}$. A qualitative approach was used because it provided a deeper understanding of the given phenomenon.

This study was conducted in a public hospital located in the Northeast of São Paulo, Brazil. The institution's tertiary care programs are considered a model of excellence for patients in urgency and emergency situations. In 1999, a proposal to decentralize the administrative structure was implemented through the adoption of shared management principles, focused on participatory decision-making with multi-professional representation in management ${ }^{(12)}$.

The main reasons for change focused on the fact that the hospital had limited and poorly managed spaces and also needed a health care oriented to the needs of the population. Thus, changes began with the hospital being segmented into thirteen functional units managed by the Coordinator, designed by the institution's superintendent; the Planning and Technical Accountability Team, the Operational Accountability Team, the Functional Unit Management Board, including 
the Managers and the Management Team and the Operational Support Group. Unit Managers and Deputy Managers need to have a higher education degree, be working in a higher-level function and be elected by a simple majority among Management Team members.

Data were collected in 2009 by interviewing 39 nursing team members from the Emergency Department and Intensive Care Unit who agreed to participate. Only one respondent refused to participate. The interview included questions about the modifications identified in nursing management after changing the management model, as well as changes identified in decisionmaking, communication and power and how these changes interfered in daily work. The interview also addressed difficulties encountered during and after the implementation process.

Inclusion criteria were: be working in the hospital during the data collection period, and be hired in 1999 or before. The sample consisted of 11 nurses (N), 27 nursing technicians (NT) and one technical health assistant (THA). Semi-structured interviews with Ns, NTs and the THA were recorded with consent, and confidentiality was assured. The interview script was submitted to face and content validation, involving four Nursing Management experts.

Content analysis was chosen among the various techniques proposed for data analysis, and includes the following analytic phases: pre-analysis, exploration of material, treatment of results, and interpretation ${ }^{(13)}$. The theoretical framework ${ }^{(8)}$ introduces four interpretations of organizational processes used in data analysis. Thus, it focused on the four-frame model, which includes the Structural, Human Resource, Political, and Symbolic frames. First, we categorized and presented qualitative interview data, and then we discussed results using the four organizational frames. The study was approved by the Hospital Ethics Research Committee (Process 3068/2008), in compliance with requirements of Resolution 196/96 of the National Health Council. Participants confirmed their interest and availability to participate and completed consent forms after being fully informed about the study.

\section{Findings}

The content analyses identified two major themes: difficulties experienced during the implementation process (Difficulties arising from the implementation process), and the return to centralized management (Returning to the Traditional Management Model).

\section{Difficulties arising from the implementation process}

Autocratic implementation and lack of team engagement

According to the interviewed institutional actors, there are advantages to this way of managing daily work in comparison with the previous way. The hospital's increased visibility is highlighted, facilitating the view of interdependence among the different production units. However, when a new process was implemented, various difficulties emerged and had to be overcome in order to achieve the desired outcomes. One of the most important aspects stressed in the participants' reports was the "strategy" used by the coordinator to implement the Participatory Management model. The vertical (top down) implementation style and lack of information concerning changes were highlighted in participants' reports as they identified that they did not know the responsibilities of each member in the group:

What happened was chaos, because professionals got lost, didn't understand what was happening or didn't know whom to turn to in order to solve problems, and there was a very big mess regarding the role of the manager, which was not welldefined. (N3)

It is clear that challenges emerged when the team was not prepared for the implications of implementing a Participatory Management model, which included multidisciplinary team leadership. Conflicts emerged when individuals were not properly informed about the responsibilities of each team member of the functional unit management team.

\section{Centralization of Power and Decision-Making}

The vertical command and decision lines were mitigated in the previously mentioned situation. Provoking alterations adherent to the Participatory Management Model definitely means change throughout an entire system of relationships and commitments. As an example, intensified participation in discussions is emphasized in the Participatory Management Model. Some employees reported that problems were solved faster after the implementation of the collective management model. However, it happened gradually and for a limited time. Some difficulties seen in some functional units since the decentralization of power, like the misinformation of workers about the proposed model management, reflected in difficulties in decision-making. Another challenge encountered relates to a new centralization of power and decision-making in the functional units: 
Those who mostly make decisions are from one professional group. Nurses are those who make decisions. (NT5)

Participatory Management principles were not being followed in all units, especially in terms of the decentralization of power and decision-making, which were perceived as still centered on physician and nursing groups. Another important finding relates to the participation of mid-level professionals-nursing technicians-in discussion forums. The Participatory Management Model implies the involvement of all stakeholders in the resolution of problems and development of proposals to improve services. In this case, these NTs felt devalued, since they perceived being included only to prevent meetings from being cancelled. Nursing technicians, a minority stakeholder in manager groups, reported that groups rarely arrived at consensus and that in-meeting voting ended up supporting interests of higher-level professionals.

[...] in important things, we low-level and mid-level professionals, our opinion doesn't count. They usually want our opinion only to make numbers, protocols. (NT16)

The limited involvement of technicians in the resolution of problems, establishment of ideas and use of creative potential was evident. These workers, perhaps due to disillusionment experienced during meetings, lost interest in being represented in the group. Several study participants reported not being informed of decisions by those representing their professional discipline and that their disciplinary power was expropriated.

Communication from top to bottom and disorganization in the daily work

The participants reported easier communication within the unit during implementation of this management style. Despite facilitation, more significant difficulties arose from lack of inter-unit communication processes. Some units presented difficulties in intensified communication at all levels during implementation, especially those whose managers were more centralized:

[...] it worked depending on the manager of each functional unit; if the manager was a communicative person, who wanted to inform the entire team about what was happening, the entire team would be informed.... (THA)

Investing effort to develop strategies that encourage communication between and within units and greater unity among professionals during problem solving is an important feature of this implementation.
Difficulty in the election of the managers

At the beginning of the implementation process, the coordinator proposed that election be used to choose managers. However, it did not happen when it was time to change this team:

An election was only carried out the first time, not the second time. The second person was placed there. (NT10)

Participants reported that an initial election was held to choose managers; however, group members had no chance to vote the second time when a manager left. For managerial groups to function optimally, each elects one manager who coordinates and supports the team. The position of this manager is strategic, and involves monitoring of plans for implementation in the functional unit. However, teams need to be able to develop close working relationships with managers, trust in and have empathy for them, and this is enhanced when managers are chosen through election.

In many cases, groups did not mobilize to appoint potential candidates for a future election, nor even manifested personal interest. This may be related to several factors, such as groups' non-adherence to model assumptions, lack of engagement, lack of knowledge, personal characteristics (authoritarianism, autocracy) and/or lack of incentive, including financial compensation and the release from part of the workload for the performance of managerial activities.

\section{Returning to the Traditional Management Model}

Implementation of the Participatory Management Model resulted in many advances, and to achieve the improvements described before, many difficulties were faced, but the departure of the coordinator in February 2003 was crucial, as it signaled the return to the previous model. Without this constant presence, an internal rearrangement enabled the return to a Traditional Management Model, despite the formal adoption of a Participatory Management Model.

I thought it was ok while [sic] was here, it wasn't what we really expected, but it was kind of ok, after [sic] left, then, it became a real mess. (NT1)

The creation of new managerial guidelines and organizational processes resulted in the achievement of solutions locally in a more contextualized and efficient manner. It seems that this was the situation in this hospital during the first coordinator's leadership period. After the coordinator's departure, multi- 
professional meetings were almost entirely eliminated and employees were again only informed of decisions after they were made. Hence, while the coordinator led the project, assumptions of Participatory Management were implemented:

The coordinator fought with many people because of this system; because of the way [sic] he saw the health system, trying to implement it... (NT12)

Successful implementation implies that the majority of those involved support and commit to the model, as commitment leads to shared responsibility. Only if the model is integrated into current practice and develops roots through concrete actions of various social actors can implementation prove effective.

When the coordinator left, things got difficult, because [sic] he was the only one here, who would back it up and hold it (the model). The others kept going until nobody cared anymore, and then, of course, the traditional model came back. (NT12)

The persistence of the coordinator was appropriate since the transition to a new management model requires time for professionals to understand and accept transformations in management style. However, concomitantly with this process, the coordinator's departure considerably hindered maintenance of the Participatory Management Model under construction.

The centralization of decision-making and power

Culminating in the coordinator's departure was a gradual return to the Traditional Management Model which brought with it centralization of power and decision-making:

It is worse than before, because power went to their heads, only that, it got a bit worse than before... I'm really hurt, sometimes I leave here really upset, people don't come and talk to you... (N1)

Even though this institution was originally considered flexible with a horizontal structure, it actually started to have a hierarchical, vertical management style, which also deconstructed the Participatory Management logic in terms of power and decision-making. This was evident when different members of the nursing team revealed they still reported to a nurse:

We have a head nurse, a head nurse on duty, you know? And we have one in charge, an operational manager and another I don't remember now who it is, but there are three levels... as it was before. (N5)

There was evidence that the nursing team, and other professionals, started to isolate themselves again and performed their work independently of others. This was a major concern, especially when interaction and inter-professional work was expected in this model.

Divisive communication

The ideals of the decentralized team were undermined when the coordinator left and workers embraced segregation, which entailed divisive and difficult communication previously rooted in the Traditional Management model.

[...] After the coordinator left, the tendency was to go back to the traditional ways, because people who composed the director's board at that time, were people who still had a background and a view based on the traditional model...Now, it seems there's a perspective. The new coordinator is asking for those who are units managers to start holding meetings, so everything turns out right, but I don't know if it will succeed. The door that gave us access to the director's room had no lock. You'd go there, knocked and were immediately attended to by whoever was there. Today, there is a lock; it's the traditional model, which imposes barriers [...] (NT12)

The decentralized Management Model provided a welcomed change, where employees were listened to and jointly discussed issues. However, return to Traditional Management led to limited employee access to management, following only established hierarchy.

\section{Discussion}

Understanding the role of the nursing service in a Traditional Management Model is relevant to the implementation of a participatory model because it is challenging to break vertical lines of command in a traditional hospital organization, as well as existing inter-professional struggles and rivalries ${ }^{(14-16)}$. A study in Malaysia showed that Participatory Management approaches were vital in achieving organizational goals, aims and objectives. Accountability was a major concern in the management process and was often lacking in participatory approaches resulting in its replacement with the 'bureaucracy model' in actual practice ${ }^{(17)}$.

In this context, to better understand difficulties identified from the implementation of this management model the four frames ${ }^{(8)}$ are discussed.

\section{Structural frame}

The Participatory Management Model brought some advantages that contributed to the advances of the hospital - an increase in internal and external visibility and improvement in care delivery. These reflect the Structural Frame with its focus on environmental 
changes $^{(8)}$. However, changing institutional structures works well when goals are clear, and when cause-andeffect relationships are well understood. When changes had been in place for a short period of time, several difficulties emerged, especially after the departure of the coordinator and visionary of the proposal.

In the structural frame, putting people in the right roles is the significant expectation. When overlaid by the political frame, with its emphasis on the need to build and maintain strong relationships for decision-making(8), one of the greatest challenges was the "top-down strategy" used by the implementation coordinator to implement Participatory Management. Although a clear need for change existed in the institution(12), internal discussions were not held on a large scale with a view to preparing for administrative reform. Nevertheless, it must be considered that, whenever the structure of an organization changes significantly, employees suffer losses because old ways of doing things are gone and new ways are not yet confirmed, leaving a messy transition period ${ }^{(18)}$. The leadership response to this is to acknowledge the losses and chaotic feelings that arise, and to work through the changes until the new structures and processes become familiar.

Demands of $21^{\text {st }}$ century healthcare environments are somewhat resistant to Traditional Management solutions to problems; thus, health services need expert decision-making skills and processes guided by innovative thinking and effective communication

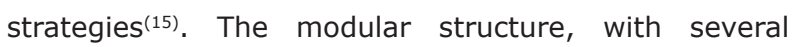
connected units of work is based on teams facilitating communication; however, interdependency between functional units can only be achieved through a broad system of intense communication(4).

Since the Participatory Management Model assumptions were not closely complied with, adherence of professionals was hindered. Loss of direction, stability, confusion, and chaos were barriers to success, and not all workers were willing to change. People refusing to accept organizational change, especially older workers, sometimes construct their own psychic prisons and then lock themselves in ${ }^{(8)}$.

\section{Human Resources frame}

The Nursing Technicians' presence as a minority in managerial groups presented another challenge, as these workers rarely succeeded in participating in discussions. To enhance quality-working relationships, hospital management should emphasize organizational- level strategies such as support for staff participation in work group activities and decision-making, formal/ informal interpersonal communication, and integrated activities to build trust and relationships among members of a work group. When the contract between the organization and staff works well, both needs are met: the organization has a satisfied workforce who provides excellent care, and the workers have meaningful work and satisfaction with their compensation ${ }^{(8)}$. However, when the centralization and control procedures for managing workers issues do not reflect workers as essential to achieving organizational goals, efforts become fragmented, performance suffers, and care is negatively affected.

\section{Political frame}

Most of the groups functioned until the coordinator's departure. After this, many of the groups became dysfunctional and although formally the model was decentralized, in practice, decision-making once again followed traditional principles of hierarchy and centralization.

Participants also reported that a first election was held to choose the managers, but was not repeated. In the Political Frame, the choice of appropriately skilled managers can be seen as a scarce resource and, therefore, the lack of repetition of this election is a significant political conflict(8). Leaders' creation of arenas where issues can be negotiated and new coalitions formed is paramount. For that to happen, however, healthcare workers must have confidence in their leader and therefore participate in the selection of a candidate to the given leadership role.

\section{Symbolic frame}

The return to the Traditional Management Model suggests that the changes were not core changes, rather were largely symbolic, not changing the meaning of work for all individuals, and therefore would not be

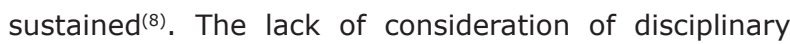
representatives as mediators to their disciplines also reflects changes that were more symbolic than deep to the core of practitioners' work. The meaning of the work had not really changed for the staff because it was still so centralized within the physician and nurse groups.

Disciplinary leaders inspire people and positively influence organizational culture through their expected leadership behavior and practices(19), especially in this model. These leaders try to engage employees; they 
frame meaning by providing plausible interpretations of experiences. They discover and communicate a vision. In this case, the leadership responded by collecting groups of staff together to review goals for change and what they would actually mean for how individual staff work, delegate, and operationalize change. The leaders also need to call those who pretend to change but do not actually suppose a real change. That kind of accountability is needed and often lacking in such contexts.

\section{Implications for Organizations undergoing change}

Communication is one of the processes that has most affected successful implementation of this model, and can be viewed through the four frames ${ }^{(8)}$. Communication is used to a) transmit facts and information with the Structural frame, b) express exchange of information, needs, and feelings within the Human Resource frame, c) focus on influence, power, or manipulation and managing conflict, to build alliances and defuse opposition within the Political frame, and d) allow people to tell stories and talk about their feelings and wishes within the Symbolic frame. When communication transmits facts and information, it is related to Human Resource frame and, when it expresses exchange of information, needs, and feelings, it is associated with Political frame because it focuses on influencing or manipulating others as well as the building of alliances and ability to defuse opposition. Communication also relates to the Symbolic frame when people tell stories and talk about their feelings and wishes.

Ten years later, characteristics inherent to Traditional Management Models are currently observed in this hospital. These include centralized power and decision-making and difficulties establishing an efficient communication process, while ideal characteristics consistent with Participatory Management are interdependent collaboration between units, open communication, and shared decision-making(20-21). Notably, there was gradual sharing of power and greater autonomy in decision-making, until the departure of the implementation coordinator.

Once an organization announces a change and starts down the road of implementation, it is important to follow through with actions, and overcome adversity. When things do not improve, the staff can become more disengaged than before which can cause great damage to all(16).
The maintenance of such implementation may require a champion to stand up to powerful groups in order to signal to them that their behavior is no longer acceptable if they keep power and decision-making to themselves. Teamwork and also the patient are influenced by the leader, whether physician or nurse. Thus, nurses and physicians should collaborate with each other and should benefit from training for conflict resolution, effective methods of asserting one's opinion, listening skills, and conducting collaborative rounds, which means shared communication and decisionmaking, and cooperation on the basis of shared power and authority(22-23).

\section{Limitations and Strengths}

This study complements the only one published in this Journal in the last two years related to the Decentralized Management Model which focused mostly on the advances of this implementation ${ }^{(10)}$. The contribution of this new study is that describes the complexity of implementing an innovative management model in a Brazilian hospital, examines dissent, gives a voice to different beliefs and intentionally acknowledges the difficulties faced by employees in the organization.

One of the limitations of this study is that the interviews were conducted only with the nursing team from two units in just one hospital. It is important to expand the study population and involve other hospitals and the interdisciplinary team to see the differences and similarities in perception in relation to the management model adopted. Another limitation refers to the fact that the process of change initiated ten years before the data collection, which means that bias may have occurred since not everyone remembers the whole process.

\section{Conclusion}

The implementation of the Participatory Management Model permitted internal improvements at the hospital institution in this study, with positive repercussions for patient care delivery, mainly during the first years of change. The nursing team's perception of this process is that communication and decisions increased soon after the implementation.

However, implementation of this model can be undermined when the team is not committed to operationalizing its underlying philosophical 
assumptions - decentralized structures, participation in team, shared responsibility and communication with stakeholder groups, participation of all team members in decision-making and qualify improvement, and greater motivation of employees in their performance. Hence, the professionals did not know what was expected of them in the new structure, or what the responsibilities of the manager group were. This important finding interacted with the "top down" implementation style to ultimately stall success of the initiative. Therefore, while the management model formally adopted was Participatory Management, the Traditional Management Model prevailed.

Importantly, it is not enough to simply restructure the organization without considering all four frames, which in combination will be most successful. How people work together (or not) will not change if leaders and managers simply restructure accountabilities without changing the actual roles and job descriptions of all team members in discussions with them. The senior administration needs to lead by example and trust their staff to choose their manager appropriately. Values and principals need to be decided on as a group, and then the teams need to identify how they will put into practice a particular value in the workplace.

Should the Participatory Management model be revisited for future implementation, we recommend that it be implemented taking into account the importance of participation and shared responsibility of all those who compose the staff of this hospital, in order to achieve success.

\section{References}

1. Parker L, Ritson P. Accounting's Latent Classicism: Revisiting Classical Management Origins. Abacus. 2011;4(2):234-65.

2. Rocha ESB, Trevizan MA. Quality management at a hospital's nursing service. Rev. Latino-Am. Enfermagem. 2009;17(2):240-5.

3. Casasnovas GL, McDaid M, Costa Font J. Decentralization and management autonomy? Evidence from the Catalonian hospital sector in a Decentralized Spain. Int Public Manage Rev. 2009;10(2):103-19.

4. Motta PR. Gestão contemporânea: a ciência e a arte de ser dirigente. Rio de Janeiro: Record; 2002. 236 p.

5. Campos GWS. Um método para análise e cogestão de coletivos. São Paulo: HUCITEC; 2000. 236 p.
6. McDowell J, Williams R, Kautz D, Madden P, Heilig A, Thompson A. Shared governance: 10 years later. J Nurs Manage. 2010;41(7):32-7.

7. Kramer M, Maguire $P$, Brewer BB. Clinical nurses in Magnet hospitals confirm productive, healthy unit work environments. J Nurs Manage. 2011;19(1):5-17.

8. Bolman LG, Deal TE. Reframing organizations: artistry, choice, and leadership. 4th ed. United States of America: Jossey-Bass; 2008. 528 p.

9. Haugaard M. Democracy, Political Power, and Authority. Soc Res: Int Q. 2011;77(4):1049-74.

10. Bernardes A, Cecílio LCO, Évora YDM, Gabriel CS, Carvalho MB. Collective and decentralized management model in public hospitals: perspective of the nursing team. Rev. Latino-Am. Enfermagem. 2011;19(4):1003-10.

11. Fachin O. Fundamentos de metodologia. São Paulo: Saraiva; 2006. 210 p.

12. Santos JS, Scarpelini S, Brasileiro SLL, Ferraz CA, Dallora MELV, Sá MFS. Evaluation of the model of organization of the emergency unit of the university hospital, Faculty of Medicine of Ribeirão Preto, University of São Paulo, based on the adoption of the national policy of emergency care and humanization as a reference. Medicina. 2003;36:498-515.

13. Bardin L. Content Analysis. Lisboa: Persona; 2007. 223p.

14. Bernardes A, Cecílio LCO, Nakao JRS, Évora YDM. Obstacles found in the construction of a democratic and participatory hospital management model. Ciênc Saúde Coletiva. 2007;12(4):861-70.

15. Bernardino E, Felli VEA. Knowledge and power necessary to reconstruct nursing after management changes at a teaching hospital. Rev. Latino-Am. Enfermagem. 2008;16(6):1032-7.

16. Kirkpatrick I, Dent M, Jespersen PK. The contested terrain of hospital management: Professional projects and healthcare reforms in Denmark. Current Sociol. 2011;4(59):489-506.

17. Hashim F, Alam GM, Siraj S. Information and communication technology for participatory based decision-making-E-management for administrative efficiency in Higher Education. Int $\mathrm{J}$ Phys Sci. 2010;5(4):383-92.

18. Bridges W. Managing Transitions: Making the most of change. 2 ed. Massachusetts: Addison-Wesley Publishing Company; 2003. 130 p. 
19. Wong CA, Laschinger $H$, Cummings GG, Vincent $L, O$ 'Connor P. Decisional involvement of senior nurse leaders in Canadian acute care hospitals. J Nurs Manage. 2010;18(2):122-33.

20. Spiers JA, Cummings GG, Langenhoff $P$, Sharlow J, Bhatti A. But we can't go back. J Leadership Studies. 2010;4(1):6-19.

21. Xyrichis A, Ream E. Teamwork: a concept analysis. J Adv Nurs. 2008;61(2):232-41.

22. Thomas EJ, Sexton B, Helmreich RL. Discrepant attitudes about teamwork among critical care nurses and physicians. Crit Care Med. 2003;31(3):956-9.

23. Dougherty MB, Larson E. A Review of Instruments Measuring Nurse-Physician Collaboration. JONA. 2005;35(5):244-53. 